Number 2008-35-36, November 7, 2008

\title{
The Mortgage Meltdown, Financial Markets, and the Economy
}

This Economic Letter is adapted from a speech delivered by Janet L. Yellen, president and CEO of the Federal Reserve Bank of San Francisco, on October 30, 2008, to the UC Berkeley-UCLA Symposium "The Mortgage Meltdown, the Economy, and Public Policy," at the University of California, Berkeley.

This conference on "The Mortgage Meltdown, the Economy, and Public Policy" could not be more timely. The mortgage meltdown is far from over, the economy and financial markets are still reeling from it, and policymakers have responded by taking some of the most momentous steps in decades. Today I'd like to consider these developments from my perspective at the Federal Reserve.

In brief, if anyone ever needed a demonstration of the strength of the links between the functioning of the financial system and the functioning of the economy, this is it. The downturn in housing construction directly weakened economic activity, while the drop in house prices precipitated a genuine crisis in financial markets, which has generated a severe credit crunch. The credit crunch, in turn, has left households and firms with fewer resources to finance spending, and as a result, output growth has weakened further and unemployment has risen. And, of course, weak output growth and higher unemployment undermine households and the housing sector, which worsens the credit crunch, which saps spending, and the adverse feedback loop goes on.

The Fed has responded both by easing the stance of monetary policy-including the 50-basis-point cut on October 29-and by supporting financial stability through enhancing market liquidity. I believe that these actions have been helpful. But, the enormity of this crisis required more. In particular, the passage of the Emergency Economic Stabilization Act of 2008 in early October made possible an infusion of capital into the financial sector, a crucial step in breaking the momentum of the adverse feedback loop.

Another approach to resolving the crisis involves addressing the problems plaguing the housing market directly, through increased aid to distressed homeowners to mitigate foreclosures or through broad-based incentives to boost the demand for housing. Such policies deserve consideration because they go to the heart of the problem, the fallout from the boom and bust in the housing market, and that is what I will turn to next.

\section{Housing}

The bust in the housing markets has, of course, been hitting the economy for some time. Although residential investment accounts for only a small share of overall economic activity, its decline over the past three years has been a major drag on real GDP growth. During this period, housing starts have plummeted and are down by over 30\% just in the past year. Yet inventories of unsold new and existing homes remain at very high levels, especially relative to sales, making it difficult to predict with any confidence when starts will bottom out.

Indeed, the possibility of ongoing contraction in this sector is intensified by the interplay of the economic downturn and the credit crunch. Understandably, financial institutions have tightened lending terms, making it more difficult to qualify for a mortgage by requiring higher down payments, higher income-to-payment ratios, and higher FICO scores. Moreover, private-label securitized markets for residential mortgages are essentially closed for business. The only remaining sources of mortgage securitization are the government-sponsored enterprises, especially Fannie Mae and Freddie Mac, which provide backing mainly for conventional conforming mortgages. 
For higher risk borrowers, the Federal Housing Administration (FHA) is close to the only game in town.

Along with the decline in construction, house prices have fallen by around 15 to $20 \%$ from their peak, depending on which measure you use. Unfortunately, this is another case where the bottom is not yet in sight. First, the ratio of house prices to rents still remains high by historical standards, suggesting that further price declines are needed to bring housing markets into long-run balance. Second, the large inventories of unsold homes I mentioned-a growing share of which are foreclosures - also can be expected to continue to put downward pressure on prices. In view of these factors, it's not surprising that futures contracts for house prices developed by Case and Shiller predict further declines.

\section{The mortgage meltdown}

The decline in house prices appears to be the crucial "falling domino" that set off the chain of distress that now plagues financial markets and the economy. Problems first appeared with the growing delinquencies and foreclosures in the subprime mortgage market. Currently, more than $20 \%$ of them are seriously delinquent (60 days or more past due) or in foreclosure. Real trouble spots include parts of Nevada, Florida, and Ohio, and here in California, the highest delinquency rates are in the Central Valley-with Merced and Stockton as leading examples.

As many of you know, the Fed has embarked on a number of studies relating to the subprime mortgage market. The research that two colleagues of mine-Paul Willen of the Boston Fed and John Krainer of the San Francisco Fed-and others have done on the variation in subprime delinquency rates across regions and over time confirms that the riskiness of the borrower pools and the quality of the underwriting standards help to explain the incidence of subprime delinquencies. However, the single best predictor of the level and change in these delinquency rates is the pace of house price increases or decreases. In fact, the research suggests that differences in house-price changes account for much of the regional differences in delinquency rates, whether borrowers are prime or nonprime, or whether loans have fixed or variable rates (Foote et al. forthcoming, Gerardi, Shapiro, and Willen 2007).

It is not hard to see why falling house prices matter so much. The amount of equity in a home affects the ability or willingness of homeowners to keep current on their mortgage payments when they face personal setbacks, such as illness, divorce, or the loss of a job. In a market in which house prices have been declining, a borrower with a recent mortgage secured with little or no down payment does not have the flexibility to tap into the equity in the house to weather these problems or may be unable to refinance or sell the house for enough to cover the outstanding mortgage balance. Moreover, in states like California, where a primary residence represents no-recourse collateral for many mortgages, some borrowers who may be able to afford their loans may nevertheless be unwilling to make the payments if house prices are expected to remain low or to decline. I would note, however, that historically many homeowners with under-water mortgages have not ended up in foreclosure.

An additional factor that intensified the effect of house price declines on subprime delinquencies is that many of those loans were designed to be bridge loans. For example, so-called 2-28 loans were set up at fairly high initial mortgage rates for borrowers with low FICO scores. If such a borrower made the payments, and if the price of the house rose as expected, the borrower would be able to refinance, presumably at a lower rate, in two years. However, once it became apparent that house prices were falling and, therefore, that the refinancing opportunity was lost, many of these loans went into default even before the initial two-year period expired.

So far, I've focused on problems with subprime mortgages. But more recently, the problems have spread: the number of serious delinquencies on alt-A loans and even adjustable-rate prime mortgages, is now on the rise. In addition, foreclosures on the 2007 vintages of mortgages are rising at about the same rate as those of earlier vintages. This is sobering, because many of the loans in these later vintages - especially those issued in the 
second half of 2007-benefited from the tighter underwriting standards put in place once the crisis hit. Most likely, then, the rising foreclosures are related not just to falling house prices, but also to the weakened economy and, in particular, to the nearly $1 \frac{1}{2}$-percentage-point increase in the unemployment rate over the past year.

The erosion in credit quality that afflicts not only subprime but also prime mortgage and home equity loans has also now spread across the full spectrum of consumer loans, including credit card, closed-end consumer, and automobile loans. These losses are compounding the pressures on financial institutions and exacerbating the resulting credit crunch.

\section{The financial system}

Some have asked why policymakers and others didn't see all of this coming. A lot of people talked about a bubble in home prices that could eventually collapse and lead to sizable credit losses and significant negative wealth effects. I think the answer is that a lot of people also did not fully understand how these effects would be magnified by several key features of the financial systemfeatures that have interacted with one another to produce a deep wariness about counterparty risk and a freezing up of credit flows. Each of these features corresponds to one of the three main elements of a balance sheet: assets, capital, and liabilities.

I'll start with assets. Here, a part of the problem is with the new securities and related derivatives that have been used extensively in this decade in mortgage finance and, in fact, throughout the financial system. They were once considered "state of the art"-dazzlingly complex, capable of spreading risk, and constructed using sophisticated mathematical models to price the risk. But it turns out that their very complexity makes it incredibly difficult now to know where the risk actually resides or how to price it, giving rise to major concerns about counterparty risk.

Turning to capital, the problem is that there is a shortage - in other words, too much leverageamong financial institutions as a whole. Capital in many banking organizations has been adversely affected because of write-downs of many of the complex instruments I referred to and because of credit losses primarily associated with delinquencies and foreclosures on real estate loans. Moreover, investment banks and other entities in the socalled shadow banking sector were very highly leveraged, with the ratio of assets to capital exceeding 30 to 1 in many cases. Such slim equity cushions increase firms' exposure to insolvency in the face of credit losses or asset write-downs.

Finally, on the liability side, the problem is that many leveraged financial institutions relied heavily on very short-term debt-often overnight loans - to fund their operations. This has made them vulnerable to "runs," especially in an environment where everyone knows that the system is exposed to impaired assets, where it is hard to determine exactly where those risks reside, and where some firms are known to have only slim equity cushions.

As financial firms have struggled to fix their own problems, the systemic consequences have become painfully apparent. Firms have tightened lending standards, trying to improve credit quality, and reduced the volume of loans. They have also been selling assets in an effort to deleverage their balance sheets. However, the simultaneous attempts of so many firms to deleverage have depressed asset prices to fire-sale levels, producing additional losses and thereby creating selling pressures for other firms holding similar positions. Write-downs on such securities are reducing the already diminished equity cushions in some firms and raising their leverage at a time when they desire less leverage, not more.

This vicious cycle has led to outright illiquidity in markets for certain asset-backed securities, making it almost impossible to determine appropriate prices and largely eliminating them as a source of new funding to borrowers. Moreover, financial institutions, and even nonfinancial firms, have become very reluctant to lend to each other, except at the shortest maturities, since they are uncertain about what demands they could face and whether they will be able to borrow to meet them; as a result, they are hoarding their liquidity. These responses have led to a greatly reduced flow of 
credit in the economy, which is the major factor responsible for the economic downturn that now is under way. In other words, we are in the grip of an adverse feedback loop in which a credit crunch exacerbates economic weakness, which in turn weakens financial institutions, intensifying the credit crunch.

\section{The economic outlook}

Indeed, recent data on the economy have been deeply worrisome. Data released on October 30 reveal that the economy contracted slightly in the third quarter. For the fourth quarter, it appears likely that the economy is contracting significantly. Mainly for this reason, inflationary risks have diminished greatly.

Over the past year or so, the FOMC has cut its federal funds rate target by 425 basis points to its current level of $1 \%$. Nonetheless, most privatesector borrowing rates are higher now than at the beginning of this crisis in August 2007. In pointing this out, I don't mean to imply that the rate cuts did no good: borrowing rates in my view would be substantially higher absent the reduction in our base lending rate. It's just that the effects of the growing credit crunch have outpaced the easing of policy, and, indeed, every major sector of the economy has been adversely affected by it.

For consumers, the credit crunch is one of several negative factors accounting for the decline in spending in recent months. Consumer credit is costlier and harder to get: loan rates are up, loan terms are tougher, and increasing numbers of borrowers are being turned away entirely. This explains, in part, the exceptional weakness we have seen in auto sales. In addition, of course, employment has now declined for nine months in a row, and personal income, in inflation-adjusted terms, is virtually unchanged since April. Furthermore, household wealth is substantially lower as house prices have continued to fall and the stock market has declined sharply.

Business spending, too, is feeling the crunch in the form of a higher cost of capital and restricted access to credit. In particular, many companies find that the financial markets have become un- receptive to their commercial paper, an important source of short-term funding. Some of our business contacts report that bank lines of credit are more difficult to negotiate, and many indicate that they have become cautious in managing liquidity, in committing to capital spending projects that can be deferred, and even in extending credit to customers and other counterparties. Nonresidential construction also is headed lower largely because of the financial crisis; the market for commercial mortgage-backed securities, a mainstay for financing large projects, has all but dried up.

Many state and local governments are being dragged deeper into the financial mess as well. The downturn in the economy has bitten into their tax revenues, and disruptions in financial markets have made it harder for them to issue bonds.

Until recently, weakness in domestic final demand was offset by a major boost from exporting goods and services to our trading partners. Unfortunately, economic growth in the rest of the world has slowed noticeably. There are a number of reasons for the slowdown abroad, including spillovers from the U.S. downturn and, most importantly, the financial meltdown that now has intensified substantially in Europe and elsewhere. In addition, the dollar has appreciated recently against the currencies of many of our trading partners, offsetting a portion of the depreciation that was boosting U.S. exports. As a result, exports will not provide as much of an impetus to growth as they did earlier in the year.

\section{Policy approaches}

Now that I've reviewed the current economic situation, I'd like to turn to policy, with a discussion of actions taken so far, and additional remedies that bear serious consideration. I've already mentioned the Federal Open Market Committee's substantial easing of monetary policy. In addition, the Fed has ramped up its use of an arsenal of liquidity tools, devising new facilities to lend directly to banks, primary dealers, money market mutual funds, and nonfinancial firms that have been frozen out of the credit markets. These facilities reduce the chance of runs on financial institutions by providing the assurance of shortterm funding from the Fed based on an expanded 
range of collateral. Beyond these facilities, the Fed has provided direct financing to prevent the outright bankruptcy of Bear Stearns and AIG, whose failure, in the judgment of the Fed and the Treasury, would have significantly undermined financial stability.

Even though the Fed has done much to attack the financial crisis, more was obviously needed. A comprehensive solution requires actions that are "fiscal," in the sense that they use taxpayer funds or place them at risk, and thus extend beyond the Fed's legislative mandate. The actions that have now been announced or implemented fall into three main categories, corresponding to the three underlying problems in the financial system that I identified earlier: impaired assets, capital shortage, and uncertainty about shortterm funding. With respect to impaired assets, the Treasury is formulating plans to purchase mortgage-related assets from financial institutions. This could reduce uncertainty about the valuation of these instruments, restore some liquidity in the secondary markets, and improve capital positions if the actual purchase prices exceed the fire-sale levels that now prevail for many assetbacked securities. The second problem afflicting the financial sector-capital shortage-is critical. It is therefore extremely heartening that the governments of all countries involved in the crisis have announced immediate plans to inject capital into their financial systems. With respect to short-term funding, direct government guarantees against default have been extended on an emergency basis to boost public confidence in lending to financial institutions. The guarantees cover most deposits as well as newly issued senior debt.

I believe that these steps are extremely constructive and will help over time to ease some of the wariness about counterparty risk and thaw credit flows. So far, we've seen very tentative signs of an easing of stress in money markets. For example, LIBOR-OIS and credit default swap spreads are down somewhat. However these spreads remain at levels that are well above normal and other measures of stress have risen even further. Clearly, we have a long way to go before the credit crunch shows significant healing. So it is worth considering other types of policies to address the crisis.

For example, several programs to mitigate the problem of foreclosures and the credit losses precipitated by falling house prices are either in effect or have been proposed. They fall into two broad categories: those aimed more or less directly at reducing the number of foreclosures by focusing mainly on helping homeowners who are at risk of losing their homes, and those designed to reduce borrowing costs for a much wider population, thereby supporting the overall demand for housing and, hence, house prices.

In the first category is the HOPE NOW Alliance, a voluntary program that started in October 2007 which brings together counselors, servicers, investors, and other mortgage market participants. It facilitates the reworking of mortgage loans by marshalling the incentives of lenders and borrowers to avoid the deadweight losses associated with foreclosures. A second example is HOPE for Homeowners, a federal program resulting from legislation sponsored by U.S. Congressman Frank and Senator Dodd. This program went into operation at the beginning of October. It expands the role of the FHA to improve loan "workout options" by providing a government guarantee of payment to lenders. In return, lenders must forgive a portion of the principal to make the new loan more affordable. In addition, the program includes a shared-appreciation feature in which the FHA and homeowner divide both the equity created at the beginning of the new mortgage loan and any future house-price appreciation.

Moreover, expanded versions of such workout approaches have been proposed. In particular, FDIC Chairwoman Sheila Bair has suggested guidelines to target and streamline the loan modification process. She also proposes using loan guarantees authorized by the Emergency Economic Stabilization Act as an incentive for servicers to lower mortgage payments so as to make them affordable and sustainable (Bair 2008a, b). Other proposals are modeled on the Homeowners' Loan Corporation instituted in the Great Depression (Roubini 2008, Blinder 2008, McCain-Palin 2008). The basic idea is that the government would 
offer to buy under-water loans-now about 15\% of total mortgages-from lenders and refinance a new mortgage for qualifying homeowners at a lower rate.

Programs like these are targeted at borrowers who are already or are likely to end up in foreclosure. They have the potential to keep qualifying homeowners in their homes with sustainable mortgages, thus avoiding the deadweight losses and negative community spillovers of foreclosure. By mitigating foreclosure sales at fire-sale prices, these programs may also support housing prices more generally and serve to limit the credit losses that have done so much damage to the financial system. The broader the debt-relief that a plan provides to households, the more it is apt to spur consumer spending and reduce credit losses; but the cost to taxpayers is likely to increase as well. Speed of implementation is another key consideration, and loan modification plans that involve dealing with and analyzing the individual situations of large numbers of borrowers tend to be quite time-consuming.

A second category of proposals is aimed at a much broader set of borrowers, and would boost the overall demand for housing by reducing borrowing costs through low-cost government loans or tax credits (Hubbard and Mayer 2008a, b, Feldstein 2008, Barack Obama and Joe Biden 2008). They hold the potential to reduce the number of foreclosures and associated credit losses both directly - by reducing after-tax house payments - and indirectly - by providing support to house prices. It is true that house prices do need to adjust, and, until they do so, potential buyers may stay out of the market (Glaeser and Gyourko 2008). However, the concern is that house prices may "overcorrect" for a number of reasons, not the least of which could be today's extraordinarily tight credit conditions. This overcorrection could have devastating effects on the financial system and the economy, and such programs seek to avoid that outcome.

My objective in discussing these ideas is not to support one plan or the other. Rather, I want to emphasize that such programs, which provide direct assistance to homeowners and the housing market, are worthy of serious consideration as additional steps beyond the policies recently adopted to address stress in financial markets. Needless to say, the pros and cons of each that I've described give just a glimpse of how difficult it will be to design approaches that are both effective and timely. Moreover, there is no doubt that, beyond these short-term strategies designed to quell the crisis, long-term, more fundamental reforms are needed as well (for example, see papers prepared for this symposium by Shiller 2008 and Hancock and Passmore 2008).

\section{Janet L. Yellen President and CEO}

\section{References}

[URLs accessed November 2008.]

Bair, Sheila C. 2008a. "A Review of Foreclosure Mitigation Efforts." Statement to the Financial Services Committee, U.S. House of Representatives, September 17. www.fdic.gov/ news/speeches/chairman/spsep1708.html

Bair, Sheila C. 2008b. "Turmoil in the U.S. Credit Markets: Examining Recent Regulatory Responses." Statement to the Committee on Banking, Housing and Urban Affairs, U.S. Senate, October 23. www.fdic.gov/ news/speeches/chairman/spoct 2308.html

Barack Obama and Joe Biden: The Change We Need. 2008. "Economy." http://www .barackobama.com/issues/economy/

Blinder, Alan S. 2008. "From the New Deal, a Way Out of the Mess." Economic View, The New York Times, February 24.

Feldstein, Martin. 2008. “The Problem Is Still Falling House Prices: The Bailout Bill Doesn't Get at the Root of the Credit Crunch." Opinion, Wall Street Journal, October 4.

Foote, C., K. Gerardi, L. Goette, and P. Willen. Forthcoming. "Just the Facts: An Initial Analysis of Subprime's Role in the Housing Crisis." Journal of Housing Economics.

Gerardi, K., A. Shapiro, and P.Willen. 2007. "Subprime Outcomes: Risky Mortgages, Homeownership Experiences, and Foreclosures." FRB Boston Working Paper 07-15. http://www.bos.frb.org/economic/wp/ wp2007/wp0715.htm 
Glaeser, Edward, and Joseph Gyourko. 2008. "The Case against Housing Price Supports." Economists' Voice 5(6) (October). http://www.bepress.com/ev Hancock, Diana, and Wayne Passmore. 2008. "Three Mortgage Innovations for Enhancing the American Mortgage Market and Promoting Financial Stability." Paper presented at "The Mortgage Meltdown, the Economy, and Public Policy," October 30, in Berkeley, California. http://urbanpolicy.berkeley.edu/ mortgagemeltdown.htm

Hubbard, R. Glenn, and Chris Mayer. 2008a. "First Let's Stabilize Home Prices." Wall Street Journal, Opinion, October 2.

Hubbard, R. Glenn, and Chris Mayer. 2008b. "House Prices, Interest Rates, and the Mortgage Market Meltdown." Paper presented at "The Mortgage Meltdown, the Economy, and Public Policy,"
October 30, in Berkeley, California. http:// urbanpolicy.berkeley.edu/mortgagemeltdown.htm McCain-Palin 2008. 2008. "Debate Facts, John McCain's American Homeownership Resurgence Plan." Comment posted at 9:10 p.m. October 7. http://www.johnmccain.com/mccainreport/ Read.aspx?guid=b73bbd90-c0ba-4fe $9-$ af 93 -87 ec54c5de $5 b$

Roubini, Nouriel. 2008. "We Need a New HOLC." Nouriel Roubini's Global EconoMonitor, September 19. http://www.rgemonitor.com Shiller, Robert J. 2008. "Policies to Deal with the Implosion in the Mortgage Market." Paper presented at "The Mortgage Meltdown, the Economy, and Public Policy," October 30, in Berkeley, California. http://urbanpolicy .berkeley.edu/mortgagemeltdown.htm 
P.O. Box 7702

San Francisco, Calif.

San Francisco, CA 94120

\section{Address Service Requested}

\begin{tabular}{ll}
\hline $4 / 18$ & $08-13-14$ \\
$5 / 9$ & $08-15$ \\
$6 / 6$ & $08-16$ \\
$6 / 13$ & $08-17$ \\
$6 / 20$ & $08-18$ \\
$6 / 27$ & $08-19$ \\
$7 / 3$ & $08-20$ \\
$7 / 11$ & $08-21$ \\
$7 / 18$ & $08-22$ \\
$7 / 25$ & $08-23$ \\
$8 / 8$ & $08-24$ \\
$8 / 15$ & $08-25$ \\
$8 / 22$ & $08-26$ \\
$9 / 5$ & $08-27$ \\
$9 / 19$ & $08-28-29$ \\
$9 / 26$ & $08-30$ \\
$10 / 3$ & $08-31$ \\
$10 / 17$ & $08-32$ \\
$10 / 24$ & $08-33$ \\
$10 / 31$ & $08-34$
\end{tabular}

The Financial Markets, Housing, and the Economy

Small Business Lending and Bank Competition

Retirement Savings and Decision Errors: Lessons from Behavioral... Did Large Recalls of Chinese Consumer Goods Lower U.S. Imports...? Speculative Bubbles and Overreaction to Technological Innovation Consumer Sentiment and Consumer Spending

Research on the Effects of Fiscal Stimulus: Symposium Summary

Monetary Policy and Asset Markets: Conference Summary

Can Young Americans Compete in a Global Economy?

Unanchored Expectations? Interpreting the Evidence from Inflation...

How and Why Does Age at Kindergarten Entry Matter?

Treasury Bond Yields and Long-Run Inflation Expectations

Regional Variation in the Potential Economic Effects of Climate...

Summer Reading: New Research in Applied Microeconomics...

The U.S. Economic Situation and the Challenges for Monetary Policy

The EMU Effect on the Currency Denomination of International Bonds

Oil Prices and Inflation

Sectoral Reallocation and Unemployment

What Is Liquidity Risk?

Monetary Policy and Asset Prices
Yellen

Laderman

Armour/Daly

Candelaria/Hale

Lansing

Wilcox

Wilson

Dennis

Cascio

Huang/Trehan

Cascio

Christensen

Butsic/Hanak/Valletta

Doms

Yellen

Hale/Spiegel

Cavallo

Valletta/Cleary

Lopez

Lansing

Opinions expressed in the Economic Letter do not necessarily reflect the views of the management of the Federal Reserve Bank of San Francisco or of the Board of Governors of the Federal Reserve System. This publication is edited by Judith Goff, with the assistance of Anita Todd. Permission to reprint portions of articles or whole articles must be obtained in writing. Permission to photocopy is unrestricted. Please send editorial comments and requests for subscriptions, back copies, address changes, and reprint permission to: Public Information Department, Federal Reserve Bank of San Francisco, P.O. Box 7702, San Francisco, CA 94120, phone (415) 974-2163, fax (415) 974-3341, e-mail sf.pubs@sf.frb.org. The Economic Letter and other publications and information are available on our website, http://www.frbsf.org. 